\title{
Sprawozdanie prezesa Polskiego Towarzystwa Teologicznego za rok 2018
}

\author{
ks. Kazimierz Panuś \\ Uniwersytet Papieski Jana Pawła II w Krakowie \\ kazimierz.panus@upjpz.edu.pl (1) https://orcid.org/0000-0002-9604-2920
}

Poprzednie walne zebranie Polskiego Towarzystwa Teologicznego odbyło się w Krakowie 27 lutego 2018. Składało się z dwóch części. W pierwszej po wysłuchaniu sprawozdań prezesa, skarbnika, kierownika Sekcji Wydawniczej i przewodniczącego Komisji Rewizyjnej udzielono absolutorium zarządowi za rok 2017.

W drugiej części walnego zebrania po laudacji ks. dr. hab. Tomasza Wielebskiego, prof. UKSW, wręczono medal Zasłużony dla Polskiego Towarzystwa Teologicznego o. prof. dr hab. Andrzejowi Potockiemu OP (Uniwersytet Warszawski) oraz wysłuchano wykładu prof. dr. hab. Andrzeja Nowaka (Uniwersytet Jagielloński): Przemiany polskiego patriotyzmu: 1768-1918-2018. Wykładem tym Polskie Towarzystwo Teologiczne włączyło się w uroczystości stulecia odzyskania przez Polskę niepodległości. Rok 2018 był drugim rokiem działalności zarządu wybranego 28 lutego 2017. Działał on w następującym składzie:

\section{Zarząd}

Prezes: ks. prof. dr hab. Kazimierz Panuś

Wiceprezes: ks. dr hab. Piotr Kroczek, prof. UPJPII

Sekretarz: o. dr hab. Romuald Kośla OFM

Skarbnik: ks. mgr Andrzej Fyda

Bibliotekarz: ks. dr hab. Jan Bednarczyk

Kierownik Sekcji Wydawniczej: mgr Sebastian Wojnowski

Komisja Rewizyjna

Przewodniczący: ks. prof. dr hab. Tomasz Jelonek 
Członkowie: ks. dr hab. Sylwester Jędrzejewski SDB, ks. dr hab. Witold Ostafiński

\section{Sąd Polubowny}

Przewodniczący: ks. prof. dr hab. Maciej Ostrowski

Członkowie: o. prof. dr hab. Tomasz Dąbek OSB, ks. dr Franciszek Ślusarczyk

Z końcem 2018 roku Polskie Towarzystwo Teologiczne liczyło 964 członków (w roku 2018 przyjęto 17 nowych). Od poprzedniego walnego zebrania do wiekuistego domu Ojca odeszli ks. prof. dr. hab. Jan Kowalski, ks. prałat Antoni Sołtysik, ks. dr Krzysztof Tadeusz Sojka, ks. infułat Janusz Bielański, ks. prof. dr hab. Jan Maciej Dyduch, bp prof. Tadeusz Pieronek oraz prof. dr hab. Andrzej Potocki OP, laureat medalu Zastużony dla Polskiego Towarzystwa Teologicznego w ubiegłym roku.

Spełniając wymogi statutowe, zarząd odbył w roku sprawozdawczym cztery zebrania: 18-19 kwietnia 2018 we Włocławku, 2 października 2018 w Krakowie, 28 listopada 2018 roku w opactwie Cystersów w Krakowie-Mogile i 26 lutego 2019 w Krakowie.

Pierwsze zebranie zarządu w roku sprawozdawczym odbyło się we Włocławku w dniach 18-19 kwietnia. Było ono złączone z obchodami 90. rocznicy powstania Teologicznego Towarzystwa Naukowego Wyższego Seminarium Duchownego we Włocławku. Zaprosił na nie wszystkich członków zarządu jego prezes, a jednocześnie kierownik Oddziału we Włocławku Polskiego Towarzystwa Teologicznego ks. dr hab. Lech Król. Zebranie zarządu odbyło się w pierwszym dniu. Na wstępie wysłuchano referatu ks. dr. Henryka Witczaka nt. Dzieje Włocławka oraz początki i rozwój struktury lokalnego Kościoła. Następnie głos zabrał ks. dr Jacek Kędzierski, dyrektor Zespołu Szkół Katolickich im. ks. Jana Długosza we Włocławku. Przedstawił on krótki rys historyczny tej placówki dydaktycznej i jej aktualne zadania. W dalszej części spotkania prezes poinformował o liście sekretarza generalnego Konferencji Episkopatu Polski bpa Artura Mizińskiego, który potwierdził odbiór pisma z uchwałą walnego zebrania oraz tekstem znowelizowanego statutu i skierował go do opinii Rady Prawnej. Prezes przedstawił także podziękowanie prof. Andrzeja Potockiego OP za przyznany mu medal oraz poinformował o złym stanie zdrowia zakonnika. W dalszej części zebrania przyjęto do towarzystwa 8 nowych członków. Spotkanie zakończyła 
modlitwa za zmarłych. Uczestnicy zebrania wpisali się do księgi pamiątkowej Teologicznego Towarzystwa Naukowego we Włocławku. W godzinach popołudniowych członkowie zarządu dzięki uprzejmości gospodarzy zwiedzili katedrę włocławską, seminarium duchowne i bibliotekę ze starodrukami, muzeum diecezjalne i budynek Zespołu Szkół Katolickich. Byli także w pobliżu tamy, gdzie znaleziono ciało bł. ks. Jerzego Popiełuszki oraz przy pomniku obrońców Włocławka w wojnie polsko-bolszewickiej 1920 roku.

Na program drugiego dnia jubileuszu (19 kwietnia 2018) złożyła się msza święta koncelebrowana, której przewodniczył bp dr Wiesław Mering, ordynariusz diecezji włocławskiej, oraz sympozjum z okazji 90. rocznicy powstania Teologicznego Towarzystwa Naukowego we Włocławku. W jego trakcie wysłuchano następujących referatów: Działalność Teologicznego Towarzystwa Naukowego Wyższego Seminarium Duchownego we Włocławku na tle działalności towarzystw teologicznych w Polsce (ks. prof. dr hab. Kazimierz Panuś); Tematyka podejmowana w „Studiach Włocławskich” w latach 1998-2018 (ks. prof. dr hab. Ireneusz Werbiński) oraz Osiagnięcia i perspektywy rozwoju działalności Teologicznego Towarzystwa Naukowego Wyższego Seminarium Duchownego we Włocławku (ks. dr hab. Lech Król). Ks. dr hab. Kazimierz Skoczylas dokonał promocji 20 tomu „Studiów Włocławskich” wydanego z okazji jubileuszu towarzystwa. Na zakończenie sympozjum prezes ks. Kazimierz Panuś wręczył bp. Wiesławowi Alojzemu Meringowi medal Zasłużony dla Polskiego Towarzystwa Teologicznego. Zarząd wyraża wielką wdzięczność ks. Lechowi Królowi i jego współpracownikom za gościnność i możliwość bezpośredniego kontaktu z „wczoraj” i „dziś” włocławskiego Kościoła.

Drugie zebranie zarządu odbyło się 2 października 2018 w Krakowie. Rozpoczął je wykład o. Romualda Kośli OFM, sekretarza Polskiego Towarzystwa Teologicznego, nt. Święty Bonawentura i jego wkład w rozwój nauki o Najświętszym Sercu Pana Jezusa. Prelegent stwierdził, że w rozważaniach Bonawentury odnajdujemy dobrze sprofilowane podstawy doktryny i kultu Serca Jezusa - antropologiczną i paschalną - które czerpią swe uzasadnienie z prawd o wcieleniu i odkupieniu. Po wykładzie głos zabrał ks. dr hab. Lech Król, który zrelacjonował obchody uroczystości 90-lecia Oddziału we Włocławku. Podkreślił, że jednym z pozytywnych aspektów jubileuszu było nawiązanie kontaktu z Włocławskim Towarzystwem Naukowym i perspektywa ściślejszej z nim współpracy. W dalszej części zebrania Sebastian Wojnowski zrelacjonował przebieg II Kongresu Towarzystw Naukowych, który odbył się w Poznaniu w dniach 14-15 września 2018. Uczestnik kongresu podkreślił 
bardzo dobrą organizację i atmosferę obrad, mimo iż kongres poza prezentacjami działalności poszczególnych towarzystw nie podjął istotnych tematów ani nie zainicjował działań na rzecz wzmocnienia roli społecznego ruchu naukowego. W dalszej części obrad ks. prof. Kazimierz Panuś zaproponował, by zwyczajne spotkania zarządu odbywały się - tak jak poprzednie - w różnych miejscach związanych z działalnością towarzystwa. Idąc za sugestią prof. Tomasza Węcławowicza, kierownika Sekcji Sztuki Sakralnej, ustalono, że następne zebranie zarządu odbędzie się w opactwie Cystersów w Mogile. Prezes uwrażliwił obecnych na potrzebę rozszerzania działalności towarzystwa o nowe oddziały terenowe i przyjmowania do nich doktorów teologii, których promotorami lub recenzentami są członkowie towarzystwa. Przedstawił również opinię Rady Prawnej Konferencji Episkopatu Polski w sprawie statutu Polskiego Towarzystwa Teologicznego przekazaną 12 września za pośrednictwem sekretarza generalnego. Zmiany wynikające z tej opinii zostaną wprowadzone do statutu przez powołaną przez zarząd komisję pod kierunkiem wiceprezesa ks. dr. hab. Piotra Kroczka, prof. UPJPII, i przedstawione walnemu zebraniu do uchwalenia. O działalności wydawniczej, w tym o kwartalniku „Ruch Biblijny i Liturgiczny” i jego umiędzynarodowieniu, a także o realizacji zadań finansowanych przez Ministra Nauki i Szkolnictwa wyższego ze środków na działalność upowszechniającą naukę mówili redaktor naczelny ks. dr hab. Stanisław Wronka oraz kierownik Sekcji Wydawniczej Sebastian Wojnowski. Kolejnym punktem zebrania była informacja prezesa o odmowie finansowania projektu badawczego dotyczącego przekładu i publikacji tekstów Grzegorza Palamasa. Z uwagi na odmowę finansowania nie odbyła się też planowana na listopad sesja o Całunie Turyńskim. Warto podkreślić, iż problematykę tę podjęła Sekcja Biblijna, współpracując z Polskim Centrum Syndonologicznym. W końcowej części zebrania nastąpiła prezentacja działalności poszczególnych oddziałów i sekcji, a do Polskiego Towarzystwa Teologicznego przyjęto 4 nowych członków.

Trzecie zebranie zarządu w bieżącym roku sprawozdawczym odbyło się 27 listopada 2018 w Opactwie Cystersów w Krakowie-Mogile. Po słowach powitania ojca opata dr. Piotra Chojnackiego oraz modlitwie przed łaskami słynącym wizerunkiem Chrystusa Ukrzyżowanego o. Mateusz Kawa OCist przybliżył zebranym etapy historycznego rozwoju opactwa, zaś prof. Tomasz Węcławowicz, kierownik Sekcji Sztuki Sakralnej, podzielił się swoimi spostrzeżeniami dotyczącymi prac renowacyjnych kościoła i klasztoru, które zostały przeprowadzone w ostatnich latach. Członkowie zarządu mogli podziwiać 
piękno wnętrza kościoła z unikatową polichromią, zwiedzili także krużganki, kapitularz, refektarz oraz bibliotekę z licznymi starodrukami. Na ręce opata zarząd składa serdeczne podziękowanie dla całej wspólnoty cystersów za zaproszenie i gościnne przyjęcie.

Spotkanie zarządu rozpoczęto od informacji na temat nowelizacji statutu towarzystwa. Wszystkie uwagi wskazane przez Radę Prawną Konferencji Episkopatu Polski zostały uwzględnione w tekście.

Kolejnym punktem obrad zarządu była organizacja walnego zebrania. $\mathrm{W}$ trakcie zebrania poruszono daleko idące zmiany w organizacji i finansowaniu badań naukowych, a przede wszystkim nowe programy, m.in. Wsparcie dla czasopism naukowych, oraz zasady sporządzania wykazów wydawnictw publikujących recenzowane monografie naukowe oraz czasopism naukowych i recenzowanych materiałów z konferencji międzynarodowych. Tę nową sytuację, w jakiej znalazły się Wydawnictwo UNUM oraz „Ruch Biblijny i Liturgiczny”, omówili ks. dr hab. Stanisław Wronka i Sebastian Wojnowski. W dalszej części zebrania ks. prof. Kazimierz Panuś przypomniał o zbliżającym się jubileuszu stulecia Polskiego Towarzystwa Teologicznego w 2024 roku i o konieczności podjęcia w niedalekiej przyszłości odpowiednich przygotowań dla godnego uczczenia tej wielkiej rocznicy. W tym celu planowane jest powołanie komitetów: honorowego i naukowego obchodów tej rocznicy. W trakcie zebrania kierownicy sekcji i oddziałów poinformowali o naukowych przedsięwzięciach mijającego roku. O. dr Andrzej Kukła CSsR zrelacjonował przebieg sympozjum poświęconego Bernardowi Häringowi, prekursorowi nowej teologii moralnej. Natomiast ks. dr hab. Franciszek Jabłoński, nowy kierownik Sekcji Misjologicznej, poinformował o dwóch ważnych sympozjach, w których uczestniczył: 90. rocznicy istnienia kleryckich kół misyjnych oraz zjazdu Towarzystwa Misjologów Polskich. Do towarzystwa przyjęto dwóch nowych członków.

Czwarte przewidziane przez statut zebranie zarządu odbyło się 26 lutego 2019 roku. Zapoznano się z nowo opracowanym statutem i postanowiono przedłożyć go walnemu zebraniu do uchwalenia. Po jego uchwaleniu przez walne zebranie zostanie on przesłany sekretariatowi Konferencji Episkopatu Polski do zatwierdzenia przez zebranie plenarne Konferencji Episkopatu Polski. Omówiono plany uczczenia setnej rocznicy powstania towarzystwa. Zgłoszono ks. dr. hab. Lecha Króla jako kandydata Polskiego Towarzystwa Teologicznego do Rady Towarzystw Naukowych przy Prezydium Polskiej Akademii Nauk. Zapoznano się ze sprawozdaniem dr. Andrzeja 
Kubanowskiego z Bydgoszczy, który reprezentował Polskie Towarzystwo Teologiczne na inauguracji Towarzystwa Naukowo-Kulturalnego w Środzie Wielkopolskiej. Przyjęto 2 nowych członków i omówiono sympozja przygotowywane przez poszczególne oddziały i sekcje.

W ramach Polskiego Towarzystwa Teologicznego działa 15 krakowskich sekcji specjalistycznych i 17 oddziałów terenowych oraz Sekcja Wydawnicza prowadząca Wydawnictwo UNUM.

\section{Działalność sekcji specjalistycznych}

Sekcja Biblijna. Kierownikiem sekcji jest ks. dr hab. Roman Bogacz, prof. UPJPII. W roku sprawozdawczym zorganizowano jedno spotkanie robocze. Odbyło się ono 8 marca w Krakowie przy ul. Bernardyńskiej 3. Na spotkaniu tym interesującą prelekcję wygłosił ks. dr Roman Mazur SDB nt. Betsaida Iulia - znane miejsce, nowa lokalizacja. Podjęto także decyzję o czynnym włączeniu się członków sekcji w seminaria poświęcone Całunowi Turyńskiemu prowadzone wraz z Polskim Centrum Syndonologicznym. Seminaria te poświęcone były następującej tematyce: Syndonologia - organizacja dyscypliny i polscy syndonolodzy w minionym stuleciu (15 marca, prowadzący: prof. dr hab. Krzysztof Pilarczyk), Datowanie radiowęglowe - badanie wieku Całunu z roku 1988 (26 kwietnia, prowadzący: prof. dr hab. Wojciech Kucewicz), Całun a ewangelie kanoniczne (17 maja, prowadzący: ks. dr hab. Roman Bogacz, prof. UPJPII) oraz Całun Chrystusa jako znak, źródło informacji oraz celowego przekazu (8 czerwca w Gdańsku, prowadzący: dr hab. Zbigniew Treppa, prof. UG). Członkowie sekcji wzięli osobiście udział w trzech pierwszych seminariach, które miały miejsce w Audytorium Maximum Uniwersytetu Jagiellońskiego przy ul. Krupniczej 33. Seminaria te były na żywo transmitowane online i są dostępne na platformie cyfrowej. W związku z setną rocznicą odzyskania przez Polskę niepodległości Sekcja Biblijna wraz z Instytutem Nauk Biblijnych oraz z Dziełem Biblijnym im. Jana Pawła II w Krakowie zorganizowała międzynarodową sesję biblijno-pedagogiczną pt. Wolność człowieka i narodu w perspektywie Pisma Świętego. Sesja odbyła się w Krakowie przy ul. Bernardyńskiej 3 w dniu 14 czerwca. 6 listopada Sekcja Biblijna wzięła czynny udział w IV sympozjum im. o. Augustyna Jankowskiego w Tyńcu pt. Psalmy - poezja czy modlitwa.

Sekcja Teologii Moralnej. Sekcję prowadzi ks. dr Bogusław Mielec. W roku sprawozdawczym kontynuowano cykl comiesięcznych spotkań 
nt. adhortacji apostolskiej papieża Franciszka Amoris laetitia. Przedmiotem badań były tzw. „dubia” czterech kardynałów oraz wpływ południowoamerykańskiej teologii miłosierdzia na VIII rozdział adhortacji. Pośrednim owocem tych poszukiwań jest książka o. prof. Jarosława Kupczaka OP pt. Źródła sporu o „Amoris laetitia” (Poznań 2018). Jej autor wyraźnie to zaznacza we wprowadzeniu do swej publikacji. W spotkaniach uczestniczy 7 wykładowców różnych dyscyplin teologicznych. Mają one charakter zamknięty, co sprzyja swobodnej i dogłębnej dyskusji, która w sposób interdyscyplinarny pozwala wejść w obszerną problematykę adhortacji.

Sekcja Homiletyczna. Kierownikiem sekcji jest ks. prof. dr hab. Kazimierz Panuś. W roku sprawozdawczym Sekcja Homiletyczna spotkała się podczas uroczystości 50-lecia istnienia Instytutu Liturgicznego Uniwersytetu Papieskiego Jana Pawła II w Krakowie. 24 października kierownik sekcji wygłosił wykład pt. Homiletyka seminaryjna w latach 1968-2018: wykładowcy, tematyka zajęć i różne formy przygotowania do posługi głoszenia słowa Bożego. Trwają też prace nad projektem pt. Kazania w kulturze polskiej. Edycje kolekcji tematycznych: kazania adwentowe, bożonarodzeniowe, wielkanocne i patriotyczne, realizowanym przez Polskie Towarzystwo Teologiczne i finansowanym w ramach Narodowego Programu Rozwoju Humanistyki w latach 2015-2019.

Sekcja Duchowości. Kierownikiem sekcji jest ks. dr Wojciech Mleczko CR. W roku sprawozdawczym kontynuowano prace związane z wieloletnim programem badań naukowych nt. Duchowość klasztorów polskich: przekaz i komunikacja. 21 lutego w krakowskim Centrum Resurrectionis wraz z Katedrą Duchowości Mediów i Relacji Społecznych Instytutu Dziennikarstwa i Komunikacji Społecznej Wydziału Nauk Społecznych Uniwersytetu Papieskiego Jana Pawła II w Krakowie oraz Zgromadzeniem Zmartwychwstania Pańskiego sekcja zorganizowała szesnaste już sympozjum z tej serii nt. Ks. Paweł Smolikowski CR: życie dla Boga, Kościoła i społeczeństwa. Przygotowano też do druku i wydano pracę zbiorową: Pomóc uchwycić sens życia: dziedzictwo ks. Waleriana Kalinki CR (red. W. Mleczko CR, Kraków 2018), która udostępnia szerokiemu gremium materiały z podobnej konferencji z 2017 roku. Nową inicjatywą, po raz pierwszy zrealizowaną w 2018 roku przez Sekcję Duchowości we współpracy z Uniwersytetem Papieskim Jana Pawła II w Krakowie oraz Zgromadzeniem Zmartwychwstańców, było Seminarium Zmartwychwstańcze. Miało ono miejsce w Centrum Resurrectionis w dniach 13-15 czerwca. Uczestniczyło w nim 12 prelegentów, w tym 3 zagranicznych. W realizacji tych zadań biorą udział przedstawiciele kilku środowisk nauko- 
wych, takich jak: Wydział Historii i Dziedzictwa Kulturowego, Wydział Nauk Społecznych, Wydział Teologiczny, Wydział Teologiczny Sekcja w Tarnowie Uniwersytetu Papieskiego Jana Pawła II w Krakowie, Instytut Teologii Duchowości Papieskiego Wydziału Teologicznego we Wrocławiu, Wydział Teologiczny Uniwersytetu Kardynała Stefana Wyszyńskiego w Warszawie, Centrum Duchowości Zmartwychwstańczej w Rzymie, Wyższe Seminarium Duchowne we Lwowie (Ukraina), Uniwersytet Jagielloński w Krakowie, Katolicki Uniwersytet Lubelski Jana Pawła II, Międzynarodowa Komisja Studiów Zmartwychwstańczych, Zgromadzenie Sióstr Zmartwychwstanek, Prowincja Polska Zgromadzenia Zmartwychwstańców, Komisja Historyczna Polskiej Akademii Nauk w Katowicach. Powzięte prace przyczyniają się m.in. do wymiany myśli, integracji środowiska naukowego oraz promowania dalszych badań nad duchową spuścizną polskich zakonów i jej oddziaływaniem. Kierownik sekcji od września 2016 roku jest konsultorem Komisji Duchowieństwa Konferencji Episkopatu Polski i członkiem zespołu ds. przygotowania nowych zasad formacji kapłańskiej w Polsce oraz członkiem dwóch międzynarodowych komisji Zgromadzenia Zmartwychwstańców: Formacji i Studiów Zmartwychwstańczych.

Sekcja Pedagogiczno-Społeczna. Kierownikiem sekcji jest ks. dr hab. Grzegorz Godawa. W roku sprawozdawczym sekcja kontynuowała serię spotkań związanych z problematyką pedagogiczno-społeczną. W jej ramach 12 czerwca przy ul. Bernardyńskiej 3 w Krakowie zorganizowano kolejne spotkanie we współpracy ze studentami Instytutu Nauk o Rodzinie Uniwersytetu Papieskiego Jana Pawła II w Krakowie. Zrealizowany projekt nosił tytuł: Na czasie - o czasie i dotyczył wartości czasu, jego przemijania i sposobów na dobre wykorzystanie każdego dnia. Do udziału w dyskusji zostali zaproszeni słuchacze Uniwersytetu Trzeciego Wieku Uniwersytetu Papieskiego Jana Pawła II w Krakowie.

Sekcja Dogmatyczna. Kierownikiem sekcji jest ks. dr hab. Jan Żelazny, prof. UPJPII. W roku 2018 sekcja zorganizowała sympozjum: Wspólna tradycja chrześcijan. Koncepcja Boga w tradycji orientalnej i zachodniej, które odbyło się 1 lutego w auli Uniwersytetu Papieskiego Jana Pawła II przy ul. Bernardyńskiej 3. Współorganizatorem sympozjum było Polskie Towarzystwo Teologiczne oraz francuska organizacja L'Oeuvre d'Orient. Stowarzyszenie to założone 160 lat temu we Francji przez profesorów Sorbony nie tylko wspomaga materialnie chrześcijan z tamtych terenów, ale stara się ocalić ich spuściznę teologiczną i kulturalną. Nie do przecenienia są ich zasługi w zachowaniu 
manuskryptów, obiektów sztuki czy pomoc wspólnotom. Sekcja dogmatyczna stara się przybliżyć tę myśl orientalną polskiemu odbiorcy.

Sekcja Misjologiczna. Po rezygnacji z funkcji kierownika sekcji misjologicznej ks. dr. Grzegorza Wity w związku z podjęciem przez niego fukcji proboszcza zarząd na zebraniu w dniu 27 lutego powierzył prowadzenie tej sekcji ks. dr. hab. Franciszkowi Jabłońskiemu, kapłanowi archidiecezji gnieźnieńskiej. W roku sprawozdawczym nowy kierownik na zebraniu Stowarzyszenia Misjologów Polskich w Warszawie 26 kwietnia zaprezentował decyzję o powierzeniu mu kierowania sekcją misjologiczną. 11 maja kierownik sekcji uczestniczył w sympozjum poświęconym 90. rocznicy Akademickiego Ruchu Misyjnego w Poznaniu. W swoim wykładzie ubogacony historią Polskiego Towarzystwa Teologicznego ukazał historię powstania kleryckich kół misyjnych w Polsce. W dniach 22-26 sierpnia ks. Jabłoński wziął udział w Światowym Spotkaniu Rodzin w Dublinie oraz w trzydniowym sympozjum teologiczno-pastoralnym i spotkaniu z papieżem Franciszkiem. W dniach 21-22 września uczestniczył w XI Zjeździe Gnieźnieńskim. W dniu 29 września odbyło się zorganizowane przez kierownika sekcji sympozjum o rodzinie w Gnieźnie. W dniach 1-3 września kierownik sekcji uczestniczył w sympozjum misjologicznym i walnym zebraniu Stowarzyszenia Misjologów Polskich w Białymstoku, wygłaszając referat o formacji misyjnej kleryków w świetle nowego ratio studiorum z 2016 roku. W grudniu wydana została książka autorska pt. Rodzina otwarta na świat i zakończone prace redakcyjne nad kolejnym rocznikiem „Studiów Misjologicznych” 8 (2018), w którym zamieszczone zostało sprawozdanie z zebrania zarządu Polskiego Towarzystwa Teologicznego w Krakowie 27 listopada 2018. Pozwoli to zapoznać członków Stowarzyszenia Misjologów Polskich z pracami Polskiego Towarzystwa Teologicznego.

Sekcja Prawa Kanonicznego. Kieruje nią o. dr Andrzej Kukła CSsR. W roku sprawozdawczym członkowie sekcji podejmowali ważne zadania dotyczące bieżących problemów prawnych w życiu Kościoła. Kierownik sekcji o. dr Andrzej Kukła prowadzi wykłady z prawa zakonnego na Università della Svizzera Italiana w Lugano (Szwajcaria) i dzięki temu nawiązał owocną współpracę z gronem profesorskim, studentami Wydziału Prawa na tymże uniwersytecie i z prof. Libero Gerosa, dziekanem Wydziału Teologii. Kierownik sekcji jest także członkiem komisji ds. nowelizacji statutu powołanej przez zarząd. Sekcja Prawa Kanonicznego w roku sprawozdawczym organizowała i współorganizowała spotkania i konferencje dotyczące problemów prawnych 
w życiu Kościoła i Państwa Polskiego. Członkowie sekcji prawa kanonicznego, którzy są często wykładowcami prawa kanonicznego w różnych seminariach duchownych i prowadzą wykłady w różnym zakresie prawa cywilnego i kościelnego m.in. na Katolickim Uniwersytecie Lubelskim Jana Pawła II, Uniwersytecie Papieskim Jana Pawła II w Krakowie, brali udział bądź byli bezpośrednio zaangażowani w organizację następujących konferencji: Zmiany $w$ kodeksie prawa kanonicznego dokonane przez papieża Franciszka w motu proprio „De concordia inter Codices” (Katedra Kanonicznego Prawa Małżeńskiego i Rodzinnego Wydziału Prawa Kanonicznego Uniwersytetu Kardynała Stefana Wyszyńskiego, Warszawa, 25 kwietnia); Obowiązi i prawa wiernych świeckich $i$ duchownych $w$ świetle Kodeksu Prawa Kanonicznego zorganizowanej przez doktorantów Wydziału Prawa Kanonicznego Uniwersytetu Kardynała Stefana Wyszyńskiego (Warszawa, 12 maja); VII Ogólnopolskiej Konferencji Naukowej nt. Kodeks Prawa Kanonicznego w badaniach młodych naukowców zorganizowanej na Katolickim Uniwersytecie Lubelskim Jana Pawła II (26 maja); Ochrona małżeństwa i rodziny w nauczaniu i ustawodawstwie papieża Franciszka zorganizowanej przez Stowarzyszenie Kanonistów Polskich, Sąd Biskupi Diecezji Rzeszowskiej, Instytut Teologiczno-Pastoralny w Rzeszowie, Wydział Nauk Prawnych Towarzystwa Naukowego Katolickiego Uniwersytetu Lubelskiego i Katedrę Kościelnego Prawa Publicznego i Konstytucyjnego Katolickiego Uniwersytetu Lubelskiego (Rzeszów, 3-5 września); Penitencjaria Apostolska - Trybunał Miłosierdzia w służbie Kościoła zorganizowanej przez Wydział Prawa Kanonicznego Uniwersytetu Kardynała Stefana Wyszyńskiego (Warszawa, 7 listopada); Polscy kanoniści w stużbie Bogu i Ojczyźnie. 100 lat prawa kanonicznego w KUL zorganizowanej przez Wydział Prawa, Prawa Kanonicznego i Administracji oraz Instytut Prawa Kanonicznego Katolickiego Uniwersytetu Lubelskiego Jana Pawła II (7 grudnia) oraz sympozjum naukowego Bernard Häring CSsR - prekursor nowej teologii moralnej zorganizowanego przez Oddział w Tuchowie, Wyższe Seminarium Duchowne Redemptorystów w Tuchowie oraz Wydawnictwo i kwartalnik „Homo Dei” w Krakowie (9 listopada). Członkowie sekcji współpracują też z Komisją Prawną Konferencji Episkopatu Polski.

Sekcja Liturgiczna. Pracami sekcji kieruje ks. dr Stanisław Mieszczak SCJ. Działalność Sekcji Liturgicznej w roku sprawozdawczym związana była organicznie z Instytutem Liturgicznym Uniwersytetu Papieskiego Jana Pawła II oraz szeroko pojętą formacją teologiczną i liturgiczną w różnych sektorach życia Kościoła krakowskiego. Sekcja prowadzi studium katechumenalne dla 
katechistów oraz sesje z duchowości liturgicznej w zgromadzeniach i seminariach duchownych (s. dr hab. Adelajda Sielepin CHR, prof. UPJPII). Członkowie sekcji prowadzą formację liturgiczną młodzieży i dorosłych oraz wykłady i ćwiczenia na kursie formacji nadzwyczajnych szafarzy komunii świętej archidiecezji krakowskiej (ks. dr hab. Janusz Mieczkowski i ks. dr Stanisław Mieszczak SCJ). Odbywa się także comiesięczna formacja teologiczno-liturgiczna oraz duchowa Diecezjalnej Diakonii Liturgicznej. Regularnie prowadzone są kursy dla fotografów, którzy chcą robić zdjęcia w czasie celebracji liturgicznych oraz współpraca z Ośrodkiem Formacji Liturgicznej w Zawichoście. Ważnym wydarzeniem, w które zaangażowani byli wszyscy członkowie Sekcji Liturgicznej, był jubileusz 50-lecia Instytutu Liturgicznego celebrowany w dniach 24 i 25 października. W jego ramach odbyło się IX Międzynarodowe Sympozjum Liturgiczne Ad Fontes Liturgicos pt. W stużbie tradycji i odnowy liturgicznej oraz uroczysta celebracja Eucharystii w kościele św. Marka. Sekcja spotykała się w tym roku także we własnym gronie, podejmując bieżące tematy z życia Kościoła oraz z przygotowaniem wyżej wspomnianego jubileuszu.

Sekcja Sztuki Sakralnej. Sekcją kieruje prof. dr hab. Tomasz Węcławowicz. W roku sprawozdawczym działania sekcji koncentrowały się na naukowych i popularnonaukowych wystąpieniach dotyczących przede wszystkim treści historycznej architektury sakralnej rozumianej jako tzw. tekst kultury. W kwietniu kierownik sekcji wziął udział w międzynarodowej konferencji naukowej pt. The Regional and Transregional in Romanesque organizowanej w Poitiers przez British Archaeological Association oraz Centre d'Études Supérieures de Civilisation Médiévale, gdzie wygłosił referat plenarny pt. Four Romanesque Cistercian Abbey Churches in Lesser Poland. Referat ten, oprócz zagadnień historyczno-artystycznych zakonu cystersów, kładł nacisk na fenomen propagowania kultów św. Floriana i św. Tomasza Kantuaryjskiego w średniowiecznej Polsce. W anglosaskiej nauce kultura religijna polskiego średniowiecza jest mało znana, toteż referat wywołał spore zainteresowanie i dyskusję. W sierpniu kierownik sekcji na zaproszenie Muzeum Ziemi Strzyżowskiej przy współpracy z parafią Bożego Ciała w Strzyżowie przeprowadził kwerendę zabytkoznawczą w kościołach dawnego pogranicza Ziemi Krakowskiej i Ziem Ruskich Korony. W rezultacie złożona została do druku analiza dotychczas nieopracowanej architektury kościoła parafialnego pw. Bożego Ciała w Strzyżowie. Natomiast w trakcie objazdów zabytkoznawczych okazało się, iż w wielu tamtejszych monumentalnych kościołach projektowanych na przełomie wieków XIX i XX przez wybitnych 
krakowskich i lwowskich architektów brak jest informacji o projektancie, jego roli i znaczeniu w dziejach architektury polskiej. Zdarzały się też informacje całkowicie błędne. W kolejnym roku kierownik sekcji planuje przekazać swe postulaty w tej sprawie tamtejszemu konserwatorowi diecezjalnemu i wspólnie rozwiązać problem. W listopadzie w trakcie zebrania zarządu w opactwie Cystersów w Mogile architekturę kościoła i klasztoru oraz rezultaty prac konserwatorskich przedstawili kierownik sekcji i jej członek o. Mateusz Kawa OCist. Ponadto o. Mateusz Kawa OCist przez cały ubiegły rok patronował w swym macierzystym klasztorze sukcesywnym pracom konserwatorskim w nawie kościoła, a przede wszystkim wspólnie z opatem kontynuował prace nad organizowaniem muzeum dokumentującego 800 lat dziejów klasztoru. Członek sekcji prof. Andrzej Włodarek kontynuował inwentaryzacje zasobów artystycznych klasztoru Sióstr Benedyktynek w Staniątkach. Ponadto współorganizował udostępnianie tamtejszych zbiorów klasztornych. Prof. Włodarek kontynuuje także równolegle prace nad zorganizowaniem muzeum w krakowskim klasztorze Klarysek. W ubiegłym roku kierownik sekcji nawiązał współpracę z ks. Mirosławem Matusznym, proboszczem pobernardyńskiego barokowego kościoła pw. Nawrócenia św. Pawła w Lublinie oraz z o. Pawłem Soleckim OFM, gwardianem klasztoru Franciszkanów w Głogówku, a zarazem kustoszem tamtejszego sanktuarium Matki Boskiej Loretańskiej, który wyraził akces do działalności w Sekcji Sztuki Sakralnej.

Sekcja Filozoficzna. Kierownikiem sekcji jest ks. dr hab. Henryk Majkrzak SCJ. W roku sprawozdawczym 27 lutego odbyło się spotkanie Sekcji Filozoficznej w klasztorze Paulinów Na Skałce w Krakowie poświęcone tematyce kolejnego tomu wydawanego przez sekcję rocznika naukowego „Theofos”. Ks. dr Wojciech Paluchowski podjął się tłumaczenia na język polski dzieła Dietricha von Hildebranda pt. Istota miłości. 25 września kierownik sekcji uczestniczył w spotkaniu naukowym ku czci św. Tomasza z Akwinu. Spotkanie zorganizowało Polskie Towarzystwo św. Tomasza z Akwinu oraz Katedra Metafizyki Katolickiego Uniwersytetu Lubelskiego Jana Pawła II. Członek sekcji dr Iwona Dafni Zogas-Osadnik dokonała przekładu największego dzieła św. Grzegorza Palamasa pt. Triady. W obronie świętych Hezychastów. Dzieło to zostanie wydane na początku 2019 roku. Członek sekcji o. dr Michał Handzel prowadził szeroko zakrojoną działalność naukową, wygłaszając wiele referatów: 16 maja w Kijowie (Ukraina) na temat filozofii Grzegorza Skoworody; 3 czerwca 2018 roku w Krakowie podczas II międzynarodowej konferencji Autyzm i Tabu nt. Myślenie obrazami - istotny element platonizmu 
i neoplatonizmu, 28 września w Krakowie podczas międzynarodowej konferencji naukowej Focus on Autism referat Wsparcie psychologiczno-pastoralne osób z ASD w kontekście etyki katolickiej, 20 listopada podczas konferencji regionalnej w Bytomiu wykład pt. Wsparcie psychologiczno-duchowe osób z ASD oraz 2 grudnia podczas ogólnopolskiej konferencji naukowej Autyzm $w$ rodzinie i edukacja w Lesznie wykład pt. Problemy moralne katolików z ASD $w$ Polsce.

Sekcja Teologii Fundamentalnej. Kierownikiem sekcji jest ks. dr hab. Damian Wąsek. W roku sprawozdawczym członkowie sekcji organizowali, współorganizowali bądź brali udział w wielu wydarzeniach naukowych. Angażowali się w sposób szczególny w inicjatywy o charakterze ekumenicznym i apologetycznym. Do konkretnych owoców działalności zaliczyć należy sympozja, publikacje artykułów naukowych i książek. Część z tych wydarzeń wiązała się z 25. rocznicą powołania Instytutu Teologii Fundamentalnej, Ekumenii i Dialogu Uniwersytetu Papieskiego Jana Pawła II w Krakowie, którego wszyscy członkowie są jednocześnie członkami Polskiego Towarzystwa Teologicznego. Z tej okazji zorganizowane zostało sympozjum naukowe Bóg, który uczy rozmawiać (18 października), podczas którego podejmowano główne zagadnienia teologiczno-fundamentalne. Referaty wygłosili między innymi następujący członkowie Sekcji Teologii Fundamentalnej: ks. prof. dr hab. Łukasz Kamykowski: Wiarygodność dialogu dziś, prof. dr hab. Andrzej Napiórkowski OSPPE: Eklezjologia integralna, ks. prof. dr hab. Krzysztof Kościelniak: Perspektywy dialogu z islamem $i$ światem muzułmańskim, ks. dr hab. Damian Wąsek: Perspektywy dialogu z nauka, ks. prof. dr hab. Tadeusz Dzidek: Perspektywy dialogu ze sztuka, dr hab. Marek Kita, prof. UPJPII: Perspektywy apologii kerygmatyczno-sapiencjalnej. To i inne wydarzenia naukowe poprzedzane były spotkaniami i konsultacjami członków sekcji. Równocześnie toczyły się spotkania wokół głównych tematów teologii fundamentalnej. Z najważniejszych książkowych publikacji naukowych członków sekcji należy wspomnieć monografię o. prof. dr. hab. Andrzej Napiórkowskiego Preegzystencja Kościoła (Kraków 2018).

Sekcja Historyczna. Jej pracami kieruje ks. dr Wacław Umiński CM. Członkowie Sekcji Historycznej zorganizowali w roku sprawozdawczym trzy zebrania: 8 listopada 2018, 13 grudnia 2018 i 10 stycznia 2019. W czasie pierwszego wysłuchano referatu Adriana Cieślika, doktoranta Uniwersytetu Papieskiego Jana Pawła II w Krakowie nt. Dominikański kult Różańca Świętego. Bractwa Różańcowe w Galicji w XIX wieku, poruszono kwestię kontynuacji 
Słownika biograficznego polskich archiwistów kościelnych (redakcja gromadzi materiały do tomu II) oraz powołano Zespół Badawczy Prozopografii Archiwistów (opiekun ks. prof. dr hab. Józef Marecki) oraz Zespół Badawczy Symboliki i Heraldyki Kościelnej (opiekun dr hab. Lucyna Rotter); zaproponowano utworzenie profilu Sekcji Historycznej na Facebooku. W trakcie drugiego zebrania wysłuchano referatu mgr. Jana Masłyka, doktoranta Uniwersytetu Papieskiego Jana Pawła II w Krakowie, nt. Wśród nocnej ciszy... niebo petne gwiazd a na Ziemi rodzi się Nadzieja oraz poruszono kwestię finansowania prac związanych ze Słownikiem biograficznym polskich archiwistów kościelnych. W trakcie trzeciego spotkania sekcji referat wygłosiła $\mathrm{dr}$ hab. Lucyna Rotter nt. Pokarm $w$ roli symbolu. Semantyczne znaczenie pokarmów $w$ kulturze europejskiej. Zachęcono uczestników spotkania do pomocy w przygotowaniu XXI Ogólnopolskiego Zjazdu Studentów Archiwistyki, które organizowane jest przez Katedrę Archiwistyki i Nauk Pomocniczych Historii Uniwersytetu Papieskiego Jana Pawła II w Krakowie, które odbędzie się w Krakowie w dniach 24-26 kwietnia 2019, a patronat honorowy nad nim będzie sprawowało Polskie Towarzystwo Teologiczne. Członkowie Sekcji Historycznej uczcili stulecie odzyskania przez Polskę niepodległości ogólnopolską konferencją naukową Drogi ku niepodległości i troska o wolność w II Rzeczypospolitej w świetle archiwaliów kościelnych (Kraków, 24 maja). Podczas konferencji referaty wygłosili następujący członkowie sekcji: ks. prof. dr hab. Józef Marecki, Legiony $w$ walce o niepodległość w świetle archiwaliów o. Kosmy Lenczowskiego OFMCap; ks. dr Wacław Umiński CM, Działania wojenne $w$ latach 1918-1920 w świetle pamiętnika kapelana ks. Andrzeja Masnego CM; mgr Adrian Cieślik, Na styku dwóch prowincji. Dominikanie na ziemiach polskich $w$ okresie odzyskania niepodległości; mgr Agnieszka Szmerek, Patriotyczne wychowanie młodzieży w szkołach pijarskich jako przejaw troski o niepodległość Polski. Członkowie Sekcji Historycznej brali udział bądź byli bezpośrednio zaangażowani w organizację następujących konferencji: Symbol - znak - rytuał. Nagość i odzienie (Uniwersytet Papieski Jana Pawła II w Krakowie oraz Gréckokatolícka Teologická Fakulta Prešovská Univerzita v Prešove, Kraków, 3-4 grudnia); Ciało, strój, biżuteria w kontekście przemian kulturowych, społecznych i politycznych drugiej połowy XX wieku (Uniwersytet Marii Curie-Skłodowskiej, Lublin, 11-12 października); Natura-Homines - Historia Interpretacje przyrody w przeszłości. Rozumienie, znaczenia, symbole (Wydział Nauk Historycznych Uniwersytetu Mikołaja Kopernika w Toruniu, 15-16 listopada). 
Sekcja Teologii Życia Konsekrowanego działa pod kierunkiem s. dr hab. Adelajdy Sielepin CHR, prof. UPJPII. W roku sprawozdawczym sekcja odbyła cztery spotkania (28 maja 2018, 2 października 2018, 4 grudnia 2018 oraz 5 lutego 2019) w klasztorze Zmartwychwstańców w Krakowie przy ul. Pawlickiego 1. Na spotkaniach członkowie sekcji prezentowali przygotowane przez siebie referaty, po których następowała dyskusja. Kontynuowano wcześniej podjęty cykl na temat powołania do konsekracji, w ramach którego na spotkaniu majowym wygłoszony został referat ks. dr hab. Wojciecha Necela TChr, prof. UKSW, nt. Charyzmat życia konsekrowanego $w$ świetle Kodeksu Prawa Kanonicznego z 1983 roku. Wszystkie artykuły i referaty napisane na ten temat są redagowane do II tomu serii Ewangelia - Proroctwo - Nadzieja, który będzie nosił tytuł Powołanie do konsekracji: teologia i duchowość. Na spotkaniach w semestrze zimowym podjęto nowy nurt tematyczny dotyczący konfrontacji życia konsekrowanego ze światem. Temat ten ukazano zarówno w ujęciu historycznym, jak i współczesnym, przybliżając aktualne problemy i oczekiwania świata wobec osób konsekrowanych. Pierwszy referat z tego cyklu na spotkaniu październikowym przedstawiła s. dr hab. Adelajda Sielepin, prof. UPJPII, na temat: Konsekracja i patriotyzm. Na kolejnych spotkaniach zostały przybliżone zagadnienia: Życie konsekrowane i zaangażowany laikat (s. dr Bogna Młynarz) oraz Konsekracja wobec walki ze złem (dr Jadwiga Zięba). W kolejnych spotkaniach podjęte zostaną jeszcze takie tematy, jak np. konsekracja i praca (zawodowa), konsekracja i nauka, konsekracja a małżeństwo, konsekracja w dialogu z innymi religiami, konsekracja a życie codzienne (wartości tego świata), konsekracja i relacje z ludźmi, konsekracja i media, konsekracja i zaangażowany laikat, konsekracja a hedonizm, konsekracja a głód duchowości, życie konsekrowane wobec tyranii hałasu, itp. Będą one stanowiły treść kolejnego tomu serii Ewangelia Proroctwo - Nadzieja, który będzie nosił tytuł Konsekracja i świat. Został też opracowany projekt wykładów rocznych z teologii życia konsekrowanego jako propozycja do seminaryjnych ratio studiorum oraz formacji zakonnej. Poza wspólnymi spotkaniami każdy z członków sekcji jest aktywny w dziedzinie wykładów, konferencji i publikacji w różnych środowiskach osób konsekrowanych.

Sekcja Syndonologiczna powstała 21 maja 2014 ze Studium Syndonologicznego prowadzonego przez wiele lat przez ks. doc. dr. hab. Jerzego Chmiela. Sekcję prowadzi ks. mgr lic. Piotr Listopad. Sekcja nie złożyła sprawozdania. 


\section{Działalność oddziałów terenowych}

Oddział w Katowic a ch. Pracami oddziału, liczącego obecnie 21 członków, kieruje ks. dr hab. Andrzej Nowicki. W roku sprawozdawczym członkowie oddziału spotkali się dwukrotnie w auli domu parafialnego parafii św. Apostołów Piotra i Pawła w Katowicach. Pierwsze ze spotkań 16 kwietnia zgromadziło oprócz członków Polskiego Towarzystwa Teologicznego - licznie przybyłych przedstawicieli świata kultury i mediów. W ramach tego spotkania wykład nt. Tajemnica cierpienia wygłosił o. dr Krzysztof Czepirski OMI. Drugie spotkanie miało miejsce dnia 15 października. W jego trakcie wykład nt. Szczęście jako odwieczne pragnienie człowieka wygłosił ks. dr hab. Andrzej Nowicki. W spotkaniach katowickiego oddziału bierze także udział zainteresowane grono studentów teologii i zaproszeni goście.

Oddział w Częs to chowie. Pracami oddziału kieruje ks. dr hab. Paweł Maciaszek. W roku sprawozdawczym Oddział w Częstochowie zorganizował trzy ważne spotkania. Na pierwszym 23 lutego w auli Wyższego Seminarium Duchownego w Częstochowie wysłuchano wykładu ks. prof. dr. hab. Marka Skierkowskiego (Uniwersytet Kardynała Stefana Wyszyńskiego) nt. Dlaczego warto być teologiem dzisiaj? Co dalej z teologia? Teologia... naukowa czy kościelna? Oprócz członków oddziału w gronie słuchaczy byli alumni sosnowieckiego i częstochowskiego seminarium duchownego, studenci Wyższego Instytutu Teologicznego w Częstochowie i kilkunastoosobowa grupa katechetów. Drugie spotkanie Oddziału w Częstochowie z udziałem arcybiskupa metropolity Wacława Depo odbyło się 12 kwietnia. Zebrani wysłuchali najpierw referatu ks. dr. Wojciecha Torchalskiego pt. Obecność Maryi w misterium Chrystusa i Kościoła w myśli teologicznej Józefa Ratzingera - Benedykta $X V I$. Po dyskusji na podjęty temat omówiono plan pracy oddziału częstochowskiego. Trzecie spotkanie, również z udziałem arcybiskupa metropolity Wacława Depo, odbyło się 12 listopada. Rozpoczęło się one nieszporami w intencji zmarłych członków towarzystwa. Następnie wysłuchano prelekcji ks. dr. Pawła Otręby nt. Rys duchowy chrześcijanina $w$ świetle kazań radiowych abp. Stanisława Nowaka. W końcowej części spotkania zebrani zapoznali się z programem przygotowywanej przez częstochowski oddział ogólnopolskiej konferencji naukowej nt. Współczesne wyzwania teologii, która ma się odbyć 9 maja 2019. Niezależnie od tych wydarzeń zarząd Oddziału w Częstochowie odbył cztery zebrania (10 stycznia, 11 lutego, 12 października i 6 listopada), przygotowując wspomniane wyżej spotkania. Warto 
nadmienić, że w roku sprawozdawczym przyjęto do towarzystwa dwóch nowych członków.

Oddział w Przemyślu. Pracami oddziału liczącego 37 członków kieruje ks. dr hab. Wacław Siwak. W dniach 1-2 maja klasztor franciszkanów w Kalwarii Pacławskiej, Biuro Promocji Kultu Męczenników Prowincji św. Antoniego i bł. Jakuba Strzemię, Wydział Historii i Dziedzictwa Kulturowego Uniwersytetu Papieskiego Jana Pawła II w Krakowie, Instytut Pamięci Narodowej Oddział Rzeszów oraz Uniwersytet Rzeszowski zorganizowali sympozjum naukowe nt. 350 lat Sanktuarium Męki Pańskiej i Matki Boskiej Kalwaryjskiej w Kalwarii Pacławskiej (1668-2018). W pierwszym dniu trwania sympozjum członkowie Oddziału w Przemyślu wygłosili dwa referaty: abp dr Adam Szal, Wkład franciszkanów w życie duszpasterskie diecezji przemyskiej, a ks. dr hab. Wacław Siwak, Kalwaryjski pogrzeb Matki Bożej w teologicznej perspektywie. Teksty tych wystąpień ukazały się drukiem w publikacji: Sanktuarium w Kalwarii Pacławskiej 1668-2018, red. Z. Gogola, Wrocław 2018. Podczas sympozjum członkowie Oddziału w Przemyślu odbyli swoje pierwsze doroczne zebranie. Drugim ważnym wydarzeniem była konferencja naukowa pt. Sanktuaria maryjne dziedzictwem kulturowym regionu zorganizowana 15 października przez Oddział w Przemyślu wraz z Towarzystwem Miłośników Sztuki Sakralnej w Przemyślu. W jej trakcie wygłoszono następujące referaty: Sanktuaria maryjne bogactwem kulturowym regionu - wprowadzenie (ks. Wacław Siwak), Wizerunek Matki Bożej Ognistej z brzozowskiej kolegiaty (ks. Maciej Marszałek), Chłopicka Matka Boża Pocieszenia (ks. Stanisław Mazur), Dąbrówkowa hodegetria (Zofia Bator), Dubiecko - kościót parafialny oraz wizerunek Matki Bożej Bolesnej (Marta Trojanowska), Matka Boża Pocieszenia z Komborni (ks. Radosław Kwolek), Obraz Matki Bożej Szkaplerznej $w$ Łańcucie (ks. Krzysztof Szczepański, ks. Marian Bocho), Apokaliptyczna Madonna z Nowosielec k. Przeworska (ks. Piotr Lasota), Kult obrazu Matki Bożej Pocieszenia w kościele Bernardynów w Przeworsku (Szymon Wilk) oraz Rymanowska Pieta (ks. Łukasz Chmielewski). Wszystkie wystąpienia zostały opublikowane w przygotowanej na konferencję książce pt. Matka Boska Podkarpacka. Mniej znane wizerunki, red. W. Siwak, Przemyśl 2018. Konferencja adresowana była głównie do nauczycieli i katechetów, jednakże grono słuchaczy stanowiło szersze gremium, w tym członkowie Oddziału w Przemyślu, którzy potraktowali swoją obecność w niej jako jedno z dorocznych zebrań. W roku sprawozdawczym trzej członkowie Oddziału w Przemyślu prowadzili wykłady w ramach studiów licencjackich z teologii dla prezbiterów ze 
specjalizacją z teologii pastoralnej (uruchomionych Uchwałą Rady Wydziału Teologicznego Uniwersytetu Papieskiego Jana Pawła II w Krakowie z 23 czerwca 2017): ks. dr Norbert Podhorecki, Metodologia ogólna, ks. prof. dr hab. Jan Twardy, Zastosowanie psychologii twórczości w pracy nad kazaniem oraz ks. prof. dr hab. Kazimierz Bełch, Duszpasterstwo ludzi $w$ drodze.

Oddział w Kalwarii Zebrzydowskiej. Pracami oddziału kieruje o. dr Roland Pancerz OFM, rektor Wyższego Seminarium Duchownego Ojców Bernardynów, przy którym działa oddział. W roku sprawozdawczym 26 maja oddział kalwaryjski we współpracy z Wyższym Seminarium Duchownym Ojców Bernardynów w Kalwarii Zebrzydowskiej zorganizował sympozjum nt. Bernardyni bydgoscy 1480-1829. W jego trakcie wygłoszone zostały następujące referaty: Kościelno-polityczny kontekst fundacji Bernardynów w Bydgoszczy w 1480 r. (ks. dr hab. Tomasz Moskal, prof. KUL), Bernardyni $w$ Bydgoszczy $w$ okresie staropolskim (ks. prof. dr hab. Andrzej Bruździński), Działalność rekatolizacyjna bydgoskich bernardynów (o. dr Alojzy Pańczak, Wyższe Seminarium Duchowne Franciszkanów), Zakonnicy bydgoskiego konwentu Bernardynów w świetle nekrologów zmarłych ojców i braci (dr Krzysztof Witkowski), Bartłomiej z Bydgoszczy i jego ślady (dr Alicja Szulc), Paweł z Łęczycy 1572-1642 (o. dr Aleksander Sitnik), Porozbiorowe losy bernardynów bydgoskich i ich materialnych dziet (dr Stefan Pastuszewski), Archiwalia bernardyńskie w zasobie Archiwum Państwowego w Bydgoszczy (dr hab. Marek Romaniuk), Bibliotheca Bernardina - zabytkowa kolekcja Wojewódzkiej i Miejskiej Biblioteki Publicznej w Bydgoszczy (dr Joanna Matyasik), Obraz św. Antoniego Padewskiego z pobernardyńskiego kościoła w Bydgoszczy (o. dr Andrzej Efrem Obruśnik), Domki loretańskie i kult Matki Bożej Loretańskiej przy klasztorach Bernardynów w Polsce (o. dr Cyprian Janusz Moryc) oraz Zarys dziejów klarysek w Bydgoszczy w XVII-XVIII $w$. (dr Patrycja Gąsiorowska).

Oddział w Tu ch owie. Pracami oddziału kieruje o. dr Maciej Sadowski CSsR. Tuchowski oddział opierał się na kadrze naukowo-pedagogicznej tutejszego Wyższego Seminarium Duchownego Redemptorystów, które w minionym roku sprawozdawczym przeżywało 115 rok swej działalności. W gronie profesorskim tuchowskiego oddziału w mijającym roku sprawozdawczym było aktywnych 31 redemptorystów, w tym 3 profesorów zwyczajnych i 3 doktorów habilitowanych. Członkowie tuchowskiego oddziału opublikowali w minionym roku 11 pozycji książkowych, 67 artykułów naukowych i popularnonaukowych, 22 recenzje, w tym recenzje wydawnicze czasopism, monografii, 
dorobku naukowego i prac doktorskich. Brali udział w kilkudziesięciu audycjach radiowych i telewizyjnych różnych stacji i rozgłośni ogólnopolskich. Gościli na 59 sympozjach i zjazdach, przy czym w 8 przypadkach byli ich organizatorami. Wygłosili też 41 referatów. Jeden z naszych utalentowanych muzycznie wykładowców ma na swym koncie w ubiegłym roku także 12 koncertów wokalnych. W roku sprawozdawczym Oddział w Tuchowie był współorganizatorem dorocznego sympozjum naukowego nt. Małżeństwo i rodzina (29-31 stycznia 2018) w ramach formacji stałej pogłębiającej duchowość apostolską w perspektywie działalności misyjno-rekolekcyjnej. Swoje referaty wygłosili profesorowie Katolickiego Uniwersytetu Lubelskiego Jana Pawła II: ks. Stanisław Dyk, ks. Andrzej Kiciński i ks. Leszek Adamowicz. 15 marca w auli tuchowskiego Seminarium z okazji święta św. Klemensa Hofbauera miał miejsce otwarty wykład gościnny wybitnego kompozytora i reżysera filmowego Dariusza Reguckiego. W dniach 5-7 listopada 2018 w Lubaszowej odbyły się warsztaty homiletyczne nt. Misja w mocy Ducha Świętego. 40 redemptorystów z Polski i zagranicy uczestniczyło w serii wykładów z zakresu homiletyki autorstwa ks. dr. Michała Dąbrówki i wypracowywało konkretne schematy kazań rekolekcyjnych. 10 listopada odbyło się w Krakowie sympozjum naukowe nt. Bernard Häring CSsR - prekursor nowej teologii moralnej. Jego współorganizatorem było krakowskie Wydawnictwo Homo Dei. Staraniem Oddziału w Tuchowie ukazał się 16 tom rocznika „Studia Redemptorystowskie. Pismo Naukowe Warszawskiej Prowincji Redemptorystów”. Z działalności Oddziału w Tuchowie w roku sprawozdawczym należy także odnotować wykład inauguracyjny w Wyższym Seminarium Duchownym Redemptorystów w Tuchowie 29 września 2018 nt. Myśl chrześcijańska w refleksji filozoficznej Hansa Ursa von Balthasara, który wygłosił o. dr hab. Marek Urban CSsR. Członkowie oddziału odbyli w roku sprawozdawczym 3 zebrania: 18 lutego, 27 czerwca oraz 29 września 2018.

Oddział w Kielcach. Pracami oddziału kieruje ks. dr Paweł Borto. W roku sprawozdawczym działalność oddziału kieleckiego Polskiego Towarzystwa Teologicznego oprócz comiesięcznych spotkań wzbogaciły dwa znaczące wydarzenia z aktywnym udziałem członków towarzystwa. Pierwszym była sesja naukowa poświęcona biskupowi kieleckiemu Czesławowi Kaczmarkowi, która odbyła się 23 października 2018 w auli kieleckiego Wyższego Seminarium Duchownego. W programie udanego organizacyjnie przedsięwzięcia referaty wygłosili: ks. prof. dr hab. Jan Śledzianowski (Biskup Czesław Kaczmarek - kapłan i pasterz diecezji), ks. dr Tomasz Gocel 
(Biskup Czesław Kaczmarek - pasterz niezłomny, prześladowany i więziony). Inspirującym było także spotkanie z Rafałem Nowakiem i Sławomirem Mazurem, twórcami filmu pt. Czesław Kaczmarek, biskup niezłomny. Sesję zakończyła Eucharystia, sprawowana w kaplicy seminaryjnej św. Kazimierza. Drugim ważnym wydarzeniem okazała się otwarta dla publiczności konferencja teologiczno-pastoralna nt. Od „Humanae vitae” do „Amoris laetitia” zorganizowana 19 listopada przez Wyższe Seminarium Duchowne w Kielcach w auli im. bp. Czesława Kaczmarka. Referaty zaprezentowali: ks. dr Marcin Kowalski (Biblijne podstawy nauki o małżeństwie $w$ Humanae vitae i Amoris laetitia), ks. dr hab. Roman Kuligowski (Znaczenie encykliki Pawła VI dla moralności chrześcijańskiej), ks. dr Jarosław Wojtkun (Kontynuacja myśli Humanae vitae w posynodalnej adhortacji Amoris laetitia czy propozycja nowego paradygmatu moralności?). Natomiast ks. dr Sebastian Wieczorek poprowadził rozmowy na temat recepcji adhortacji posynodalnej papieża Franciszka Amoris laetitia z perspektywy świadectw małżeństw. Konferencję zwieńczyła dyskusja panelowa. Oddział w Kielcach kontynuował prace nad przystosowaniem „Kieleckich Studiów Teologicznych” do funkcjonowania na platformie Open Journal Systems. Sekretarz oddziału ks. Zbigniew Trzaskowski wygłosił 24 maja referat na temat: Hymn o miłości Pawła z Tarsu-spojrzenie literaturoznawcy na Uniwersytecie Rzeszowskim podczas Ogólnopolskiej Interdyscyplinarnej Konferencji Naukowej Życie bez miłości jest (nie)możliwe (24-25 maja) z udziałem 35 przedstawicieli środowisk uniwersyteckich i naukowych.

Oddział w Sand omierzu. Pracami oddziału kieruje ks. dr hab. Roman Bogusław Sieroń, prof. KUL. Oddział liczy 30 osób i działa przy Instytucie Teologicznym im. bł. Wincentego Kadłubka w Sandomierzu. W roku sprawozdawczym oddział sandomierski podjął wiele form działalności. Członkowie oddziału współorganizowali i brali udział w czterech konferencjach naukowych: Jubileusz nauczycieli, wychowawców i katechetów w ramach obchodów jubileuszu 200-lecia diecezji sandomierskiej (3 marca), Świeccy Kościoła sandomierskiego. Jubileusz świeckich w ramach obchodów jubileuszu 200-lecia diecezji sandomierskiej (21 kwietnia), Wyzwania duszpasterskie diecezji sandomierskiej. Sympozjum podsumowujące obchody 200-lecia diecezji sandomierskiej (20 października) oraz Ogrody biblijne i sakralne (1 grudnia). Członkowie oddziału sandomierskiego wzięli również udział w 20 krajowych i zagranicznych konferencjach naukowych, wygłaszając referaty, prowadząc obrady, bądź w nich uczestnicząc. Prowadzono także wzmożoną działalność wydawniczą, 
czego owocem jest ukazanie się 31 pozycji książkowych i artykułów naukowych zamieszczonych zwłaszcza w kwartalniku „Społeczeństwo i Rodzina” redagowanym przez kierownika oddziału. Ks. dr hab. Roman Bogusław Sieroń, prof. KUL, oraz ks. dr hab. Tomasz Moskal, prof. KUL, opracowali wiele haseł osobowych dla Encyklopedii 100-lecia Katolickiego Uniwersytetu Lubelskiego (t. 1-2, red. E. Gigilewicz i in., Lublin 2018).

Oddział w Tarnowie. Kierownikiem oddziału jest ks. prof. dr hab. Janusz Królikowski. Oddział nie złożył sprawozdania.

Oddział w Rzeszowie. Kierownikiem oddziału jest ks. dr hab. Andrzej Garbarz, prof. UR. W 2018 roku członkowie oddziału prowadzili działalność naukowo-dydaktyczną w Wyższym Seminarium Duchownym w Rzeszowie, w Instytucie Teologiczno-Pastoralnym, na Uniwersytecie Rzeszowskim, na Politechnice Rzeszowskiej oraz w Wyższej Szkole Informatyki i Zarządzania w Rzeszowie. Podejmowano współpracę w formie organizacji i czynnego udziału w konferencjach, sympozjach i szkoleniach. Prowadzono systematyczną współpracę z Kuratorium Oświaty w Rzeszowie (zwłaszcza ks. mgr lic. Andrzej Cypryś) oraz z rzeszowskim oddziałem Civitas Christiana. 18 kwietnia w Instytucie Teologiczno-Pastoralnym im. św. Józefa Sebastiana Pelczara w Rzeszowie Wydział Katechetyczny Diecezji Rzeszowskiej zorganizował sympozjum katechetyczne Wychowanie do patriotyzmu. W sympozjum, w którym uczestniczyło ok. 200 osób, aktywnie włączyli się członkowie towarzystwa. Brali oni także czynny udział w kilku konferencjach i szkoleniach dla nauczycieli i katechetów organizowanych przez Kuratorium Oświaty w Rzeszowie. 28 kwietnia odbył się w Instytucie Teologiczno-Pastoralnym etap diecezjalny XXII Ogólnopolskiego Konkursu Wiedzy Biblijnej zorganizowany przez Civitas Christiana. Komisji konkursowej przewodniczył ks. dr Marek Dzik, Moderator Dzieła Biblijnego w Diecezji Rzeszowskiej. W konkursie wzięło udział 100 osób. 26 czerwca w Instytucie Teologiczno-Pastoralnym odbyła się konferencja naukowa Między zaangażowaniem a kontestacją. Kulturowe $i$ historyczne czynniki zmiany społecznej. Konferencję zorganizowano we współpracy z Uniwersytetem Kardynała Stefana Wyszyńskiego w Warszawie. W dniach 3-5 września Instytut Teologiczno-Pastoralny w Rzeszowie był gospodarzem Ogólnopolskiej Konferencji Naukowej i Zjazdu Towarzystwa Kanonistów Polskich. Konferencja podjęła temat: Ochrona małżeństwa i rodziny $w$ nauczaniu i ustawodawstwie papieża Franciszka. Odpowiedzialnym za organizację konferencji był ks. dr hab. Piotr Steczkowski. Członkowie towarzystwa opublikowali szereg artykułów, zwłaszcza popularno- 
naukowych, w diecezjalnej prasie oraz prowadzili audycje w Katolickim Radiu VIA.

Oddział w Bielsku-Białej. Kierownikiem oddziału jest ks. dr Robert Samsel. Oddział liczy aktualnie 45 członków i działa w siedzibie kurii diecezji bielsko-żywieckiej w Bielsku-Białej przy ul. Żeromskiego 5a. W roku sprawozdawczym odbyły się dwa spotkania. 14 maja zorganizowany został panel dyskusyjny członków towarzystwa na temat aktualnych zagadnień teologicznych, a 12 listopada odbyła się prezentacja książki kierownika oddziału ks. dr. Roberta Samsela pt. Świętość i święci wyniesieni na ołtarze przez Jana Pawła II jako paradygmat teologiczny, edukacyjny i zjednoczeniowy. Zebrani zapoznali się z poruszaną tam problematyką teologiczną. Kontynuowana jest również współpraca z Uniwersytetem Trzeciego Wieku działającym przy Akademii Techniczno-Humanistycznej w Bielsku-Białej. W ramach współpracy członkowie towarzystwa prowadzą wykłady lub prelekcje o tematyce teologiczno-filozoficzno-religijnej.

Oddział w Radomiu. Kierownikiem oddziału jest ks. prof. dr hab. Marek Jagodziński. W roku sprawozdawczym oddział był współorganizatorem ogólnopolskiej konferencji naukowej pt. Wiara i rozum dzisiaj. Encyklika „Fides et ratio" wobec wyzwań współczesnego świata, która odbyła się 15 listopada w Wyższym Seminarium Duchownym w Radomiu. W sesji pierwszej wysłuchano następujących referatów: Wiara i rozum czy rozum i wiara-pytanie o pierwszeństwo: Anzelm z Canterbury i Jan Pawet II (prof. dr hab. Maciej Manikowski, Uniwersytet Wrocławski); Błogosławiony ołów obciążający pośpiesznie wzbijające się do lotu (acz nieukształtowane) skrzydła... Czyli o potrzebie racjonalnej, krytycznej i powściagliwej refleksji nad relacjami między rozumem a wiara - ratio et fides i wiara a rozumem - fides et ratio (dr hab. Marek Rębierz, Uniwersytet Śląski), Spór (dialog) między wiarą a rozumem jako element konstytutywny rozwoju nauki (dr hab. Wiesław Wójcik, Uniwersytet HumanistycznoPrzyrodniczy im. Jana Długosza w Częstochowie). Natomiast w sesji drugiej przybliżono następujące zagadnienia: Sztuczna inteligencja - od idei do transformacji rzeczywistości (ks. dr hab. Józef Kloch, prof. UKSW), Encyklika „Fides et ratio" - w kierunku prawdy integralnej (ks. prof. dr hab. Marek Jagodziński, Katolicki Uniwersytet Lubelski Jana Pawła II) oraz Rozum i wiara a kultura $w$ świetle encykliki „Fides et ratio” (ks. dr Wojciech Wojtyła, Uniwersytet Technologiczno-Humanistyczny im. Kazimierza Pułaskiego w Radomiu).

Oddział w Sosnowcu. Kierownikiem oddziału, liczącego aktualnie 37 członków jest ks. prof. dr hab. Jan Orzeszyna. W roku sprawozdawczym 
odbyły się łącznie cztery spotkania, w tym jeden dzień skupienia, dwa sympozja naukowe i jedno spotkanie organizacyjne. To ostatnie poświęcone zaplanowaniu pracy oddziału w roku akademickim 2018/2019 miało miejsce 31 sierpnia 2018. W jego trakcie wykład nt. Katecheta we współczesnej szkole wygłosił ks. prof. dr hab. Zbigniew Marek (Akademia Ignatianum, Kraków). Wielkopostny Dzień Skupienia (17 marca) dla członków i sympatyków Oddziału w Sosnowcu odbył się w budynku Wydziału Katechetycznego Kurii Diecezjalnej w Sosnowcu. W jego trakcie ks. dr Paweł Pielka (Uniwersytet Papieski Jana Pawła II w Krakowie) wygłosił wykład nt. Jak wierzyć w Kościół? Warto podkreślić ogromną wagę i sukces zorganizowanych przez oddział sosnowiecki sympozjów naukowych. Pierwsze z nich odbyło się 15 września. Rozpoczęło się ono Eucharystią, której przewodził ks. dr. Michał Borda, sekretarz oddziału sosnowieckiego, a homilię o Duchu Świętym wygłosił ks. dr Michał Knapik. W trakcie obrad zebrani wysłuchali następujących referatów: Posłannictwo Kościoła i nauka społeczna (dr Michał Kosche), Podstawowe zasady katolickiej nauki społecznej (dr Magdalena Kosche) oraz Misja i statut Katolickiego Stowarzyszenia Civitas Christiana (Mateusz Zbróg). Drugie sympozjum naukowe, upamiętniające 100-lecie niepodległości Polski, zostało zorganizowane przez Oddział w Sosnowcu 20 października. Wziął w nim udział bp dr Grzegorz Kaszak. W trakcie obrad wysłuchano następujących wykładów: Z Siewierza na służbę Rzeczypospolitej. Dr Leon Korusiewicz dyplomata, historyk, patriota (dr hab. Lech Krzyżanowski, Uniwersytet Śląski); Kościół katolicki w Zagłębiu Dąbrowskim w okresie stalinizmu (dr hab. Adam Dziurok, prof. UKSW) oraz Rola i zadania katechezy w wychowaniu patriotycznym dzieci i młodzieży (ks. prof. dr hab. Tadeusz Panuś, Uniwersytet Papieski Jana Pawła II w Krakowie).

Oddział w Szczecinie. Kierownikiem oddziału działającego przy Wydziale Teologicznym Uniwersytetu Szczecińskiego jest ks. prof. dr hab. Andrzej Offmański. W roku sprawozdawczym oddział szczeciński zorganizował 4 konferencje naukowe, które cieszyły się dużym zainteresowaniem. Pierwsza z nich 24 lutego poświęcona była zagadnieniu: Nasze miejsce we wspótczesnym Kościele. Uczestniczyły w niej 82 osoby. Wysłuchano dwóch referatów: Współczesne problemy z tożsamością Kościoła (ks. prof. Tadeusz Czapiga, Uniwersytet Szczeciński) oraz Upodmiotowienie laikatu odejściem od modelu Kościoła klerykalizowanego (ks. dr Kazimierz Półtorak). Kolejna konferencja nt. „Najbardziej po Panu Bogu kocham Polskę” - 100 lat niepodległości Ojczyzny naszej odbyła się 17 kwietnia. 32 uczestników wysłuchało dwóch 
referatów: Odbudowa państwa polskiego w 1918 roku (prof. dr hab. Janusz Faryś, Uniwersytet Szczeciński) oraz Udział Kościoła w zachowaniu polskiej tożsamości narodowej (ks. dr hab. Grzegorz Chojnacki, Uniwersytet Szczeciński). W dniach 11-12 czerwca odbyły się w Trzęsaczu XV Nadbałtyckie Debaty Katechetyków Polskich, konferencja naukowa zorganizowana przez Katedrę Katechetyki Wydziału Teologicznego Uniwersytetu Szczecińskiego wraz z oddziałem szczecińskim Polskiego Towarzystwa Teologicznego. Tym razem były one poświęcone wychowaniu patriotycznemu w katechezie i w nauce religii. Konferencja składała się z trzech sesji: Fundamenty, Uwarunkowania oraz Propozycje wychowania patriotycznego. W obradach udział wzięli bp Marek Mendyk i bp Wojciech Osial z Komisji Wychowania Katolickiego Episkopatu Polski oraz 50 uczestników. Oprócz tych 3 konferencji Oddział w Szczecinie kontynuował cykl otwartych wykładów pt. Ocalić od zapomnienia, poświęconych upamiętnieniu pionierów Kościoła nad Odrą i Bałtykiem. 24 listopada w sali konferencyjnej Kurii Metropolitalnej w Szczecinie wygłoszono referaty przypominające trzy wielkie postacie: $B p$ Teodor Bensch - pierwszy powojenny biskup na Ziemiach Zachodnich i Pótnocnych Polski (ks. dr. Jan Mazur), Ks. Józef Anczarski - z Kresów Wschodnich na Pomorze (ks. dr. hab. Grzegorz Wejman, prof. US) oraz O. dr Władysław Siwek TJ - twórca duszpasterstwa akademickiego w Szczecinie (dr Zbigniew Stanuch, Instytut Pamięci Narodowej Oddział w Szczecinie). W posiedzeniu udział wzięli abp Andrzej Dzięga, metropolita szczecińsko-kamieński, bp Henryk Wejman, senator Edmund Bilicki oraz 27 uczestników, członków towarzystwa.

Oddział w Toruniu. Pracami oddziału kieruje ks. prof. dr. hab. Dariusz Zagórski. W roku sprawozdawczym Oddział w Toruniu zorganizował dwa spotkania naukowe: 7 lutego oraz 24 października. Oddział toruński objął swym patronatem konferencję: Chrześcijański Orient. Historia, dziedzictwo, współczesność (Toruń, 15-16 maja) oraz kolejną edycję TEKA (TeologicznoEtnologiczna Konferencja Akademicka): A Human - Prayer and Meditation (14 czerwca). Kierownik Oddziału wydał też książkę pt. 25 lat Wyższego Seminarium Duchownego Diecezji Toruńskiej (1993-2018).

Oddział we Włocławku. Kierownikiem oddziału jest ks. dr hab. Lech Król. W roku sprawozdawczym odbyły się cztery spotkania w Wyższym Seminarium Duchownym we Włocławku, w tym pierwsze było spotkaniem roboczym, drugie - jubileuszowym z okazji 90. rocznicy powstania Towarzystwa Teologicznego we Włocławku jako Oddziału Polskiego Towarzystwa Teolo- 
gicznego we Lwowie (o czym była już mowa wyżej), a pozostałe dwa miały charakter wykładów otwartych. W spotkaniach otwartych uczestniczyli członkowie Towarzystwa, osoby życia konsekrowanego, alumni seminarium duchownego, świeccy z Włocławka i okolicy. Zarząd Oddziału we Włocławku zapraszał na wykłady otwarte nauczycieli i katechetów oraz członków różnych ruchów parafialnych z miasta i okolicy. Nawiązano też owocną współpracę z Włocławskim Towarzystwem Naukowym. W roku sprawozdawczym przygotowano do druku i wydano kazania bł. bp. Michała Kozala. Tą źródłową edycją uczczono 80. rocznicę święceń biskupich błogosławionego, które otrzymał w katedrze włocławskiej w sierpniu 1939 i 80. rocznicę jego uwięzienia przez okupacyjne władze niemieckie (7 listopada 1939). Staraniem Oddziału we Włocławku wydano też obszerne dzieło (1314 stron) ks. dr. hab. Witolda Kujawskiego, prof. UMK, pt. Parafie diecezji włoctawskiej: okres kujawsko kaliski 1818-1925 (Włocławek 2018). Autor monografii zamieścił w niej dedykację: „Dla upamiętnienia 90. rocznicy powstania Towarzystwa Teologicznego we Włocławku”. Warto dodać, że wydawany przez oddział włocławski rocznik naukowy „Studia Włocławskie” jest indeksowany w Baz-Hum, dlatego też wszystkie artykuły są na bieżąco digitalizowane i dostępne na stronie internetowej: http://bazhum.muzhp.pl/czasopismo/774/.

Oddział w Pelplinie. Oddziałem liczącym obecnie 36 członków kieruje ks. prof. dr. hab. Janusz Szulist. W roku sprawozdawczym doroczne spotkanie statutowe odbyło się 15 października w Kurii Diecezjalnej Pelplińskiej. Ponadto oddział pelpliński współorganizował wraz z Kurią Diecezjalną, Zrzeszeniem Kaszubsko-Pomorskim oraz Wydziałem Teologicznym Uniwersytetu Mikołaja Kopernika IV Areopag Pelpliński nt. Miłość małych $i$ wielkich ojczyzn. Ta ogólnopolska konferencja odbyła się w dniach 24-25 lutego. Oddział w Pelplinie zorganizował także spotkanie otwarte dla wszystkich zainteresowanych w dniu 15 października. W jego trakcie ks. dr hab. Jarosław Babiński, prof. UKSW, wygłosił wykład pt. Metafizyczny sens starości. Próba porównania stanowisk antropologicznych ks. Franciszka Sawickiego i Bogusława Wolniewicza. Staraniem oddziału wydano dwie książki: ks. Janusz Szulist, Troska o środowisko naturalne $w$ społeczeństwie. Komentarz do encykliki „Laudato si” papieża Franciszka oraz Opieka nad osobą starszą. Studium moralno-społeczne, red. Janusz Szulist, Wojciech Cichosz.

Oddział w Elblągu jest najmłodszym z oddziałów. Prowadzi go ks. dr Krzysztof Kaoka. Oddział nie złożył sprawozdania. 


\section{Uwagi końcowe}

Do najważniejszych dokonań zarządu Polskiego Towarzystwa Teologicznego w Krakowie w roku sprawozdawczym należy zaliczyć nowelizację statutu.

Polskie Towarzystwo Teologiczne realizuje projekt Kazania $w$ kulturze polskiej. Edycje kolekcji tematycznych finansowany przez Ministra Nauki i Szkolnictwa Wyższego z Narodowego Programu Rozwoju Humanistyki, mający na celu opracowanie do 2019 roku czterech antologii kazań: adwentowych, bożonarodzeniowych, wielkanocnych i patriotycznych. W staraniach o finansowanie badań naukowych i publikacji ich wyników godne podkreślenia są wysiłki kierownika Sekcji Wydawniczej Sebastiana Wojnowskiego.

Na szczególne uznanie zasługuje ożywiona działalność oddziałów we Włocławku (który w 2018 roku obchodził 90-lecie swej działalności), w Sandomierzu i Szczecinie oraz krakowskich sekcji specjalistycznych - biblijnej, teologii życia konsekrowanego, duchowości i sztuki sakralnej.

Polskie Towarzystwo Teologiczne jest kościelną osobą prawną o zasięgu ogólnopolskim, stąd zarząd na ręce abp. prof. dr. hab. Marka Jędraszewskiego, arcybiskupa metropolity krakowskiego, oraz księży biskupów obecnych na walnym zebraniu składa serdeczne podziękowanie Konferencji Episkopatu Polski za troskę władz kościelnych o rozwój towarzystwa. Zarząd dziękuje również wszystkim aktywnym członkom towarzystwa, którzy mimo wielorakich trudności czynią wszystko, aby działalność towarzystwa była kontynuowana i służyła dalszemu uwrażliwieniu polskiego społeczeństwa na myśl teologiczną. 